$\begin{array}{ll}\text { ISSN } & \text { 0974-3618 (Print) } \\ & \text { 0974-360X (Online) }\end{array}$

\section{$\underline{\text { RESEARCH ARTICLE }}$}

\title{
Ecological-Geochemical Features of the Trace Elements Distribution in Arable Soils and Parent Bedrocks in the Conditions of Slope Relief
}

\author{
Anzhela G. Gadzhikerimova, Larisa L. Novykh \\ Belgorod State University, 308015, Pobedy Street, 85, Belgorod, Russia \\ *Corresponding Author E-mail: russia@ prescopus.com
}

\begin{abstract}
:
The contents of trace elements $\mathrm{Mn}, \mathrm{Cu}, \mathrm{Pb}, \mathrm{Zn}, \mathrm{Cr}, \mathrm{Ba}$, and $\mathrm{Sr}$ in soils and parent bedrocks in the conditions of sloping terrain of the river valley were studied. The comparison of their concentrations with the clarkes of soils and lithosphere, maximum permissible and approximate permissible concentrations, regional background concentration was conducted. The index of total pollution of soils was calculated, the tightness of correlation was defined. The heterogeneity of soil-forming bedrocks and soils in the conditions of slope relief was identified. The content of elements in rocks is low the clarke of the lithosphere (with the exception of $\mathrm{Cr}$ ). In the soils the accumulation of $\mathrm{Cu}, \mathrm{Pb}, \mathrm{Zn}$ in comparison with clark was revealed, as well as exceeding MPC for $\mathrm{Cr}$. The accumulation of $\mathrm{Sr}, \mathrm{Pb}$ and $\mathrm{C}$ in the arable layer of the soils in comparison with the regional background was found. Topsoil contamination by pollutants is acceptable.
\end{abstract}

KEYWORDS: Heavy metals, Clarkes of concentrations, maximum allowable concentrations, regional background concentration, the index of total pollution of soils.

\section{INTRODUCTION:}

Environmental pollution is the negative side result of the human agricultural activity. The soils of the Belgorod region are subjected to extreme pressure: in the structure of lands agricultural lands occupy $96.0 \%$, including $79.5 \%$ of arable land. Such high figures of the agricultural development are explained by the fact that more than $70 \%$ of the area is represented by the chernozems. The feature of the region is the predominance of slope type of relief, which occupies $72 \%$ of the total area. For today the soil contamination by trace elements called "heavy metals" is quite wellstudied; in some sources their biogeochemistry, bioavailability, the impact on the environment and human health, soil pollution in different regions of the world were observed [1,2,3].

Received on 26.11.2016

Accepted on 16.01.2017

Modified on 28.12.2016

(C) RJPT All right reserved

Pharm. and Tech. 2017; 10(3): 773-777.

DOI: 10.5958/0974-360X.2017.00145.7
Currently the separation of heavy metals on the "classic heavy" and "heavy alkaline earth» is occurred. Little is known about the nature of the of soil contamination by heavy alkaline earth metals ( $\mathrm{Sr}, \mathrm{BA}$ ), due to the difficulty of their diagnosis, although the authors note that almost all urban soil visibly are contaminated by technogenic strontium and barium [2]. In recent years, the publications devoted to the patterns of trace elements distribution in soils of the Belgorod region have been appeared [4]. Here with the authors observe only the arable layer of soils. The aim of our research was to study the trace elements pollution of soils and soilforming bedrocks under the active agricultural activities in the conditions of slope relief. The features of the distribution of the following metals: $\mathrm{Mn}, \mathrm{Cu}, \mathrm{Pb}, \mathrm{Zn}, \mathrm{Cr}$, $\mathrm{Ba}$ and Sr. were studied.

\section{MATERIALS AND METHODS:}

The study was carried out on the experimental plot in the Belgorod research Institute of agriculture, located in the Belgorod region in the valley of the river Erik, on the South slope exposure, the steepness was varied from $1^{\circ}$ to $5^{\circ}$. On this site, the studies of the soil changes in conditions of the zonal and landscape systems of 
agriculture are conducted. The orography is represented by the weakly expressed sink micro relief. In the soil cover of the area the chernozems typical on the loess loams are dominated. In September 2014, the stage of field studies was held, including drilling 12 wells to the depth of 3 and 5 meters. During the morphological descriptions of the soils it was found that the soil cover is represented by agrochernozems and agro-dark gray gleysoils. Among the agrochernozems the hydro metamorphosed and migratory-micellar sub types are represented. The presence of the several types of parent bedrock son the site was determined: among them there are alluvial, loess-like and cover loams, cover clays. Determination of the trace elements was conducted on the x-ray fluorescence spectrometer SPECTROSCAN MAX - GV. The reaction of the soil environment $(\mathrm{pH})$ was determined by the potentiometric method on the device "testo 206". Determination of the granulometric composition of soils was carried out in the Centre of agrochemical service "Belgorodskyi". To determine the coefficients of concentration $(\mathrm{Cc})$ of elements, the ratio contents of elements in soil or bedrock in relation to the clarke of soil or the lithosphere were calculated by A. P. Vinogradov [5].To determine the degree of soil pollution the comparison of the elements concentrations with the maximum allowable or approximate permissible concentration (MPC and APC) as well as with the regional background concentration was conducted.

\section{RESULTS AND DISCUSSION:}

Manganese $(\mathrm{Mn})$ is the element, the geochemistry of which is called "paradoxical" because the processes of concentration, dispersion, oxidation and recovery are going seemingly against the laws of thermodynamics [6]. Usually it is accumulated in the upper layer of soil due to the fixation by organic matter. In the Belgorod region the average background content of $\mathrm{Mn}$ in the arable layer of soil is $361 \pm 40 \mathrm{mg} / \mathrm{kg}$, the distribution of the element along the profile has uniform nature [4]. Copper $(\mathrm{Cu})$ in soils, as a rule, is accumulated in the upper horizons, which reflects the bioaccumulation of this element, as well as modern anthropogenic influence [7,8]. In the Belgorod region the $\mathrm{Cu}$ content in arable soils is 13.5 $\mathrm{mg} / \mathrm{kg}, 6.5 \mathrm{mg} / \mathrm{kg}$ below clarke [4]. Lead $(\mathrm{Pb})$ is a dangerous heavy metal, but the soil it is strongly inactivated and loses its toxicity [2], it refers to particularly dangerous elements (1 class of danger). In arable soils in Belgorod region the content of $\mathrm{Pb}$ is 14.3 $\mathrm{mg} / \mathrm{kg}$, which is above the clarke $4.3 \mathrm{mg} / \mathrm{kg}$ [4].Zinc $(\mathrm{Zn})$ is an important trace element, it is vitally essential for plants, so for some soils the zinc fertilization is necessary [2,9]. In the Belgorod region the content of zinc in arable soils is $44 \mathrm{mg} / \mathrm{kg}, 6 \mathrm{mg} / \mathrm{kg}$ below clarke [4]. Chromium (Cr), according to [10], creates a high ecological danger of natural eco systems pollution. He belongs to the group of rare metals; therefore, fluctuations of its concentration leads to changes in the chemical balance in the environment that impact directly or indirectly on human health. Some authors consider that there is no risk of chromium contamination in global scale, but it is possible local high concentrations of chromium in soil, water or atmosphere [11]. Although chromium pollution is strongly influenced upon soil biological activity, it is not included in the national list of dangerous elements [2]. In the arable layer of the Central Russian upland soils, the content of $\mathrm{Cr}$ is $44 \ldots 130 \mathrm{mg} / \mathrm{kg}$ [12]. According to [13], barium is adsorbed on clay particles, so it can be expect the increase of its concentration in heavy granulometric composition of soils. The solubility of barium compounds depends on the acid-base conditions: with the $\mathrm{pH}$ decrease it increases. Background content in the arable layer of soils of the Belgorod region is equal to $374.4 \pm 13.9 \mathrm{mg} / \mathrm{kg}$ [14]. The background $\mathrm{Sr}$ concentrations in the arable layer of soils and subsoils can vary in broad limits [15].Often the content of barium and strontium compare, calculating the ratio :Sr [2]. The background $\mathrm{Sr}$ concentrations in the arable layer of soils of the Belgorod region is equal to $53.6 \pm 7.2 \mathrm{mg} / \mathrm{kg}$ [14]. In the analysis the horizons of the studied soils were divided into two types - organo-mineral and mineral - and parent bedrocks were allocated. Table 1 shows the concentration ratios of the elements relative to theclark of soil by A. P. Vinogradov in the two studied soils.

Table 1 The coefficients of concentration $(\mathrm{Cc})$ of elements in relation to the clark of soil

\begin{tabular}{llllll}
\hline \multirow{2}{*}{ Elements } & \multicolumn{2}{l}{ Agrochernozem migratory- micellar } & Agro-dark gray gleysoil & \\
\cline { 2 - 5 } & Organo-mineralhorizons & Mineralhorizons & Organo-mineralhorizons & Mineralhorizons \\
\hline $\mathrm{Mn}$ & 0.62 & 0.60 & 0.45 & 0.35 \\
$\mathrm{Cu}$ & 2.05 & 1.68 & 1.70 & 1.74 \\
$\mathrm{~Pb}$ & 2.10 & 1.85 & 1.83 & 1.76 \\
$\mathrm{Zn}$ & 1.28 & 1.12 & 1.18 & 1.12 \\
$\mathrm{Cr}$ & 0.52 & 0.48 & 0.60 & 0.63 \\
$\mathrm{Sr}$ & 0.34 & 1.01 & 0.34 & 0.20 \\
$\mathrm{Ba}$ & 1.00 & 0.96 & 1.00 & 0.96 \\
\hline
\end{tabular}

Regularities of distribution in the other studied soils are $(\mathrm{Cc}=1.1-1.3)$, and scatter: $\mathrm{Cr}(\mathrm{Cc}=0.5-0.6)$, and $\mathrm{Mn}$ similar. It was ascertained that the most significantly $(\mathrm{Cc}=0.3-0.6)$. accumulate: $\mathrm{Pb}(\mathrm{Cc}=1.8-2.1), \mathrm{Cu}(\mathrm{Cc}=1.7-2.0), \mathrm{Zn}$ 
The Mn content in the organo-mineral horizons of agrochernozems is higher than in the parent bedrocks: $528 \ldots 500 \mathrm{mg} / \mathrm{kg}$ compared to $201 \ldots 304 \mathrm{mg} / \mathrm{kg}$. The same regularity was observed for $\mathrm{Zn}: 63 \ldots 75 \mathrm{mg} / \mathrm{kg}$ vs $39 \ldots 55 \mathrm{mg} / \mathrm{kg}$. At the same time for agro-dark gray gleysoil the regularity for $\mathrm{Zn}$ is another: its content in the upper horizon of the soil practically does not differ from the content in the rock ( 59 and $63 \mathrm{mg} / \mathrm{kg}$ ). The content of the chalcophile elements in organo-mineral horizons is 1.1-1.5 times higher than in the bedrocks: for $\mathrm{Cu}$ it is $34 \ldots 40 \mathrm{mg} / \mathrm{kg}$ compared to $14 \ldots 29 \mathrm{mg} / \mathrm{kg}$ and for $\mathrm{Pb}-$ $18 \ldots 21 \mathrm{mg} / \mathrm{kg}$ and $13.16 \mathrm{mg} / \mathrm{kg}$, respectively. Again the Agro-dark gray gleysoilis allocated, in which the content of chalcophile elements in the organo-mineral horizons is almost identical to the content in the bedrock. According to the publications, $\mathrm{Cr}$ is characterized by the absence of biogenic accumulation in the humus horizon and by uniform distribution along the profile [14]. The chromium level in soils varies greatly and depends on the composition of the parent bedrocks on which soils were formed [16]. $\mathrm{Cr}$ accumulation was not also revealed in the organo-mineral horizons of the studied soils, which corresponds to the published patterns of this element behavior. Its content was $99 \ldots 119 \mathrm{mg} / \mathrm{kg}$, and in the bedrocks $-109.120 \mathrm{mg} / \mathrm{kg}$. The content of $\mathrm{Sr}$, according to [15], may vary within wide limits: $6 . .2010$ $\mathrm{mg} / \mathrm{kg}$ in topsoil and $8 . . .3120 \mathrm{mg} / \mathrm{kg}$ in the subsoil. The average content of $\mathrm{Sr}$ in this case is $89 \mathrm{mg} / \mathrm{kg}$ and 95 $\mathrm{mg} / \mathrm{kg}$, respectively. In the studied soils the content of $\mathrm{Sr}$ in organo-mineral horizons varies in the range of $103 \ldots 130 \mathrm{mg} / \mathrm{kg}$, and in the bedrocks $-152 \ldots 318 \mathrm{mg} / \mathrm{kg}$, which in general coincides with published data. For the European soils the weak correlation between $\mathrm{Sr}$ and $\mathrm{CaO}$ contents was determined [15]. In the studied soils and bedrocks such correlation was not detected. Clear differences between content in organo-mineral horizons of the studied soils and in parent bedrocks have not been identified: $483 \ldots 515 \mathrm{mg} / \mathrm{kg}$ and $463 \ldots 494$ $\mathrm{mg} / \mathrm{kg}$, respectively. Clarke ratio of $\mathrm{Ba}: \mathrm{Sr}$ is 1.7 [2]. For the studied soils and rocks it is 3.9...4.9 for organomineral horizons, 1.67 .9 ...for mineral horizons and 1.5...3.1 soil-forming rocks. The study plot is characterized by the variety of parent bedrocks due to the sloping nature of the relief and the action of the river on the litho logical features of the bedrocks. Table 2 shows the content of elements in the parent bedrocks compared with the standard world clarke of the lithosphere. It was established that clark of $\mathrm{Cr}$ was exceeded (Cc 1.3-1.4). All other elements are characterized by the dispersion, thereby forming the following series: $\mathrm{Mn}>\mathrm{Cu}>\mathrm{Sr}>\mathrm{Zn}>\mathrm{Ba}>\mathrm{Pb}$, i.e. manganese is characterized by the most scattering, lead. Doesn't scatter and close to the clarke of the lithosphere Thus, soil-forming bedrocks of the plot differ by the lower content of the studied elements in comparison with the clarke of the lithosphere, with the exception of chromium. The comparison of the three types of bedrocks shows that the alluvial loams have minimum concentrations of all the elements, except chromium and loess-like loams - maximum concentrations.

Table 2 The coefficients of concentration (Cc) of elements in relation to the clarke of lithosphere by A.P. Vinogradov

\begin{tabular}{llll}
\hline \multirow{2}{*}{ Elements } & \multicolumn{2}{c}{ ypes of sol forming bedrocks } \\
\cline { 2 - 4 } & Alluvial loams & Loess loams & $\begin{array}{l}\text { Covering loam } \\
\text { sandclays }\end{array}$ \\
\hline $\mathrm{Mn}$ & 0.20 & 0.30 & 0.21 \\
$\mathrm{Cu}$ & 0.31 & 0.62 & 0.50 \\
$\mathrm{~Pb}$ & 0.79 & 1.00 & 0.95 \\
$\mathrm{Zn}$ & 0.47 & 0.66 & 0.63 \\
$\mathrm{Cr}$ & 1.45 & 1.32 & 1.44 \\
$\mathrm{Sr}$ & 0.45 & 0.94 & 0.47 \\
$\mathrm{Ba}$ & 0.71 & 0.75 & 0.76 \\
\hline
\end{tabular}

To assess the degree of soil contamination with chemical substances the indicator "maximum permissible concentration" (MPC) is used in Russia. According to [17], MPC in soil is represented as complex index of chemical substances in the soil, harmless to humans; the criteria, using in the justification of its level, reflects the possible exposure routes of the contaminant over the contact environment, soil biological activity and processes of its self-purification. Often for risk assessment of soil contamination the degree of protection of soil eco systems is taken into account, for example, low risk $-95 \%$ of the soil organisms are protected, dangerous condition -to $50 \%$ of soil organisms are not protected [18]. In Canada, when evaluating the content of barium in the soil, the nature of land use Is taken into account: for agricultural land, the standard is $500 \mathrm{mg} / \mathrm{kg}$, and for residential and industrial areas - $2000 \mathrm{mg} / \mathrm{kg}$ [13]. The MPC values and approximate permissible concentrations (APC) to assess the degree of pollution of soils and bedrocks were taken from official sources $[19,20]$. For it is recommended to use the value of the MPC according to foreign sources, as in Russia, the limit of its content in soils is not normalized [21]. Noteworthy, is the clear contradiction between the background gross chromium content in soil and maximum permissible concentrations of this element. As noted in [12], Clarke of chromium in soil is 2 times higher than the MPC values. In different sources the different levels of chromium are given: 100 $\mathrm{mg} / \mathrm{kg}$ [12] or $200 \mathrm{mg} / \mathrm{kg}$ [2]. In our work we used the first of these values, as it was used by the authors of the cited work for soils of the Belgorod region. The evaluation results showed that in the organo-mineral and mineral horizons of all studied soils the concentration of $\mathrm{Cr}$ is at the level of the MPC or larger than 1.1-1.3 times. $\mathrm{Sr}$ values are exceeding the maximum permissible concentration only in one of the wells. However, as it is pointed out by Yu. N. Vodyanitskii [2], the action level does not take into account the partial nature of the genesis of pollutants, whereby the danger is overstated 
on the area of positive geochemical anomalies, and it is underestimated within the area of negative anomaly, therefore, it is necessary to take into account the regional background and provincial natural conditions for determining the extent of soil contamination. In this regard, we have been calculated the excess of the regional background concentrations in arable layer of soil for 6 elements (table. 3) as for the $r$ data of background values in the Belgorod region soils does not exist. For the arable layer of soils the following regularities are marked: the excess of the background for $\mathrm{Sr} 2.7$ times and $\mathrm{Pb} \quad-\quad 2.1$ times (agrochernozemhydrometamorphized); for $\mathrm{Sr} 2.1$ times and for $\mathrm{Zn}, \mathrm{Pb}, \mathrm{Cu}-1.8-2.1$ times (aagrochernozemclayilluvial); for $\mathrm{Pb}, \mathrm{Cu}, \mathrm{Sr}$ in 2 and more times (agrochernozemmigratory-micellar); for $\mathrm{Sr}$ and $\mathrm{Pb} 2$ times (agro- dark gray gley soil) It can be assumed that the accumulation of $\mathrm{Sr}$ in the arable layer of the soil is associated with the application of phosphorus fertilizers, where it is a mixture. According to [22], phosphorus fertilizers are the significant source of strontium, because they contain from 0.5 to $4 \%$ of this element. Elevated levels of lead can be related to its stability in organic soils, where the average period of its saving is estimated by hundreds or thousands of years [2].

Table 3 Exceeding of the regional background concentrations in the topsoil of the studied soils

\begin{tabular}{|c|c|c|c|c|c|c|}
\hline \multirow[t]{2}{*}{ Soils } & \multicolumn{6}{|c|}{ Elements } \\
\hline & $\mathrm{Mn}$ & $\mathrm{Cu}$ & $\mathrm{Pb}$ & $\mathrm{Zn}$ & $\mathrm{Sr}$ & $\mathrm{Ba}$ \\
\hline Agrochernozemhydrometamorphized & 1.70 & 1.76 & 2.10 & 1.51 & 2.74 & 1.41 \\
\hline Agrochernozemclay-illuvial & 1.68 & 1.89 & 1.97 & 1.92 & 2.13 & 1.30 \\
\hline Agrochernozem migratory-micellar & 1.74 & 2.03 & 2.22 & 1.43 & 2.00 & 1.34 \\
\hline Agro- dark gray gley soil & 1.30 & 1.52 & 2.04 & 1.25 & 2.14 & 1.38 \\
\hline
\end{tabular}

To assess the level of chemical contamination of soils, he calculation of a comprehensive index of the total contamination of soils (Zc) has been carried out, formulated by taking in to account geochemical and geo hygienic researches [17]:

$\mathrm{Zc}=\sum(\mathrm{Cci}+\ldots+\mathrm{Ccn})-(\mathrm{n}-1)$,

\section{Where}

Cci - concentration coefficient of the i-th component of pollution, $\mathrm{Cc}=\mathrm{i} / \mathrm{bi}$,

$\mathrm{i}-\mathrm{e}$ actual content of the defined substance in soil, $\mathrm{mg} / \mathrm{kg}$;

bi - regional background levels of substances in soil, $\mathrm{mg} / \mathrm{kg}$;

$\mathrm{n}-$ Number of the defined summarized substances.

The value of $\mathrm{Zc}$ in the topsoil of the studied soils varied from 3.5 to 9.0 , that is contamination of the arable layer can be considered valid ( $\mathrm{ZS}<16)$.

To study the interaction between the elements we have been calculated the closeness of correlation connection. The close direct relationship between $\mathrm{Mn}$ and $\mathrm{Cu}$ was determined, the weak direct link between $\mathrm{Zn}$ and $\mathrm{Cu}, \mathrm{Pb}$, and $\mathrm{Cu}, \mathrm{Pb}$ and $\mathrm{Mn}, \mathrm{Zn}$, and Mnwas found and the weak inverse connection between $\mathrm{Cu}$ and $\mathrm{Sr}$. When assessing the influence of the granulometric composition and acidbase properties of soils on the content of the studied elements it was discovered the close connection between the content of silt particles and $\mathrm{Cu}(\mathrm{r}=0.82)$ and the content of silt particles and $\mathrm{Mn}(\mathrm{r}=0.80)$. Also the weak inverse relationship between the $\mathrm{pH}$ values and content of $\mathrm{Mn}, \mathrm{Cu}, \mathrm{Pb}$ was revealed, and the weak direct correlation between $\mathrm{pH}$ values and $\mathrm{Sr}$ content.

\section{CONCLUSION:}

Despite the large number of publications concerning the problems of soils contamination by heavy metals the scientific works assessing the degree of contamination of different types of soils in different landscape conditions continue to remain relevant due to the diversity of the litho geochemical background. To enhance the reliability of the study's results it is necessary to resolve several issues connecting the development of MPC and APC. In particular, it requires the removal of the contradiction between the background total chromium content in soil and maximum permissible concentrations of this element. Also it requires the strengthening of works on rationing the content of barium in the soils, because the using of foreign sources of MPC does not take into account regional peculiarities of Russian soils. The use of unified MPC values for the source depleted and enriched by heavy metal soils is problematic when comparing the content of heavy metals in the soils of different granulometric composition. In this regard, the submitted conclusions are valid for heavy loamy and clay soils.

\section{RESUME:}

1. In the organo-mineral and mineral horizons of the studied soils it is noted the excess of the clark of soil for $\mathrm{Pb}, \mathrm{Cu}$, and $\mathrm{Zn}$; the contents of $\mathrm{Cr}$ and Mnare lower then clarke. In parent bedrocks in comparison with the global conditional clarke of the lithosphere the slight excess of $\mathrm{Cr}$ was revealed; $\mathrm{Pb}$ is close to clark of lithosphere; the content of other elements is below clark.

2. In comparison with the regional background concentration in the topsoil of the studied soils the accumulation of $\mathrm{Sr}, \mathrm{Pb}$ and $\mathrm{Cu}$ is taken place. In general, 
the contamination of the total arable layer by pollutants can be considered valid $(\mathrm{Zc}<16)$.

3 . The close direct correlation between the content of manganese and copper, silt particles, and manganese, silt particles and copper was revealed

\section{REFERENCES:}

1. Adriano, D., 2001. Trace elements in the terrestrial environment. New-York - Berlin -Heidelberg-Tokio: Springer-Verlag, pp: 796.

2. Vodyanitskii, Y.N., 2014. Biogeochemistry of contaminated soils. Publishing house of Moscow state University after Lomonosov, p.: 290

3. Chao, S., LiQin, J., WenJun, Z., 2014. A review on heavy metal contamination in the soil worldwide: Situation, impact and remediation techniques. Environmental Skeptics and Critics, 3(2): 24-38.

4. Lukin, S.V., Khizhnyak, R.M., 2012. Geographical distribution patterns of trace elements in soils of the Belgorod region. Advances in science and technology of AIC, 5: 55-58.

5. Vinogradov, A.P., 1962. The average content of chemical elements in main types of igneous rocks of the earth's crust. Geochemistry, 7: 555-571.

6. Yudovich, Y.E., 2012. Paradoxes Geochemistry of manganese. Bulletin, 5:19-24.

7. Oviasogiea, P., Aghimiena, A., Ndiokwereb, C., 2011. Fractionation and bioaccumulation of copper and zinc in wetland soils of the Niger Delta determined by the oil palm. Chemical Speciation and Bioavailability, 23(2): 95-109.

8. Zhi-Ting Xiong, Hai Wang, 2005. Copper Toxicity and Bioaccumulation in Chinese cabbage (Brassica pekinensisRupr.). Department of Environmental Sciences, Wuhan University, pp: 188-194.

9. Rehm, G., Schmitt, M., 2016. Zinc for crop production. Regents of the University of Minnesota. Date Views 25.03.2016. www.extension.umn.edu/agriculture/ nutrientmanagement/micronutrients.pdf.

10. Barałkiewicz, D., Siepak, J., 1999. Chromium, Nickel and Cobalt in Environmental Samples and Existing Legal Norms. Polish Journal of Environmental Studies, 4: 201-208.

11. Wyszkowska, J., 2002. Soil Contamination by Chromium and Its Enzymatic Activity and Yielding. Polish Journal of Environmental Studies, 11 (1): 79-84.

12. Lukin, S.V., 2011. Monitoring of the chromium content in crops and soils. The achievements of science and technology, agriculture, 6: 54-55.

13. Canadian Soil Quality Guidelines for the Protection of Environmental and Human Health, Barium, 2013. Canadian Council of Ministers of the Environment. Date Views 24.03.2016. http://ceqg-rcqe.ccme.ca.pdf.

14. Goleusov, P.V., Artyschev, V.E., Morabandza, K.B., 2015. Ecological and geochemical characteristic of post settlement of geo systems in the Belgorod region. Modern problems of science and education. Date of access 21.03.2016 www.scienceeducation.ru/

15. Strontium, 2015. A contribution to IUGS/IAGC Global Geochemical Baselines. Date Views 26.03.2016. http://weppi.gtk.fi/publ/foregsatlas/Sr.pdf

16. Agency for Toxic Substances and Disease Registry, 2015. Date Views 22.03.2016. http://www.atsdr.cdc.gov.pdf.

17. Guidelines MU 2.1.7.730-99., 1999. Hygienic assessment of soil quality in populated areas. Moscow: Inf-ed. center of Minzdrav of Russia, p: 25.

18. Ecological Risk Assessment for the Standard Mine Site, 2007. Wildlife Risk CalcsV3.xls: HQ Report, pp: 154

19. GN 2.1.7.2041-06. MPC of chemical substances in soil, 2006. Moscow: Publishing house of standards, p: 14.
20. GN-09. APC of chemicals in the soil, 2009. Moscow: Publishing house of standards, p.: 11.

21. Kopylov, I.S., 2012. Litho geochemical spatial distribution patterns of trace elements in the Western Urals. Vestnic of Perm University, 2 (15): 16-34. опылов . . 2012.

22. Belyuchenko, I.S., 2014. Features of mineral waste and the feasibility of their use in the formation of complex composts. The scientific journal of the Kuban state agrarian University, 101(07): $1-21$. 